УДК 159.9.072.432

doi: 10.15330/ps.9.1.11-16

Svitlana Kuzikova

Sumy State Pedagogical University named after A.S. Makarenko

kuzikova_svetlana@ukr.net

Valeriy Zlivkov

Institute of Psychology named after G.S. Kostyuk NAPS of Ukraine

vzlivkov@gmail.com

Svitlana Lukomska

Institute of Psychology named after G.S. Kostyuk NAPS of Ukraine

svitluk@ukr.net

\title{
CONTEMPORARY INTEGRATIVE INTERPERSONAL THEORY OF PERSONALITY: KEY CONCEPTS
}

This article is devoted to the concept of integrative interpersonal theory of personality. The origins of the interpersonal theory of personality are found in interpersonal theory of psychiatry. This approach facilitates interdisciplinary conceptualizations of functioning and treatment by emphasizing the interpersonal situation as a prominent unit of analysis, organized by the metaconstructs of agency and communion and the interpersonal circumplex model. The interpersonal circumplex can serve as both companion and guide for those interested in exploring the interpersonal domain of personality. It is outlined the major assumptions and key concepts of the contemporary integrative interpersonal theory of personality. The features and the variety of studies, including several recent studies that extend integrative interpersonal theory are outlined. It is established that applications of the model for exploring both the idiographic (person-centered) and nomothetic (variable-centered) realms of personality. The contemporary interpersonal tradition assumes a pathoplastic relationship between interpersonal functioning and many forms of psychopathology. Key concepts of interpersonal theory: Copy process, Catalysts of internalization, Interpersonal motives, Regulatory Metagoals are described. The interpersonal nexus in psychology is a nomological net that provides the architecture to coordinate definition of personality. Given the advances in interpersonal theory and description discussed here, we would argue that agentic and communal personality characteristics should be essential components of an interdisciplinary science of personality psychology.

Keywords: interpersonal approach, interpersonal circumplex, personality, self-realization, communication.

Introduction. The interpersonal perspective in personality, clinical and social psychology provides an integrative framework for the study of psychosocial personality functioning. Interpersonal theory emphasizes the importance of interpersonal functioning, and theorists working within this tradition have developed the interpersonal circumplex (IPC) to organize the ways in which interpersonal functioning can be characterized. Commonly, interpersonal phenomena are understood to unfold over time, and often involve individuals behaviorally adapting to the demands of a situation. An individual's internal processes (e.g. affect, appraisals, motives) influence his or her overt interpersonal behavior (e.g. hostility, warmth), which in turn constrains the reactions of interaction partners. Over time, these responses from others tend to maintain the initial actor's internal experience and overt behavior, and foster stable patterns of interpersonal experiences and relationships. The present study is an initial attempt to describe the key aspects of integrative interpersonal theory of personality.

Analysis of literature data and problem definition. The interpersonal tradition (D. J. Kiesler; R. LaForge; T. Leary; C. J. Hopwood, E. B. Ansell, A. L. Pincus, A. G. Wright, M. R. Lukowitsky, M. J. Roche) has conceptualized personality as an individual's characteristic interpersonal style: «Personality is the relatively enduring pattern of recurrent interpersonal situations that characterize a human life» (H. Sullivan, 1953, pp. 110-111). Interpersonal theory has developed in concert with a geometric structural model of personality, which was based on the seminal work of T. Leary. This model accounts for personality at various levels of interpersonal functioning such as traits (J. S. Wiggins, N. Phillips, P. Trapnell) [10], behaviors (D. S. Moskowitz) [9], values, interpersonal efficacy (K. D. Locke, P. Sadler) [8], covert reactions to others (D. J. Kiesler) [6], and interpersonal problems (L. E. Alden, J. S. Wiggins, A. L. Pincus) [11]. 
Contemporary integrative interpersonal theory of personality is based on interpersonal psychology (A. G. Wright, M. R. Lukowitsky) [1], interpersonal psychotherapy (J. Johnson, M. M. Weissman, G. L. Klerman) [5] and integrative interpersonal model of personality psychopathology (C. J. Hopwood, E. B. Ansell, A. L. Pincus) [3].

Modern interpersonal psychology is now at a point where recent advances need to be organized so that researchers, practitioners, and students can understand what is new, different, and state-of-the art. Sullivan's emphasis on the interpersonal situation as the focus for understanding both personality and psychopathology set an elemental course for psychiatry and clinical psychology. He suggested that persons live in communal existence with the social environment and are motivated to mutually seek basic satisfactions (generally a large class of biologically grounded needs), security (i.e., anxiety-free functioning), and self-esteem. Advances over the last two decades allow the contemporary interpersonal tradition in clinical psychology to serve as an integrative nexus for defining, describing, assessing, and treating personality disorders (C. J. Hopwood, E. B. Ansell, A. L. Pincus) [3]. This interpersonal nexus of personality disorders has evolved, in large part, due to the highly integrative nature of interpersonal theory itself (L. M. Horowitz, S. E. Rosenberg, B. A. Baer) [4]. For example, contemporary interpersonal theory can accommodate findings from a number of research traditions that bear upon the social manifestations of and contributions to personality pathology. A potential misinterpretation of the term «interpersonal» is to assume it refers to a limited class of phenomena that can be observed only in the immediate interaction between two proximal people. In contemporary interpersonal theory, the term interpersonal is meant to convey a sense of primacy, a set of fundamental phenomena important for personality development, structuralization, function, and pathology. This allows the contemporary interpersonal tradition to incorporate important pantheoretical representational constructs such as cognitive interpersonal schemas, internalized object relations, and internal working models (M. R. Lukowitsky, M. J. Roche) [3].

The interpersonal legacy that emerged from Sullivan's work is now in its fifth generation and has evolved in level of theoretical integration, methodological sophistication, scope, and application. CIIT consolidates these advances into a paradigm (J. S. Wiggins, N. Phillips, P. Trapnell) [10], or a meta-theory (E. B. Ansell, A. L. Pincus) for psychological science [3].

Interpersonal psychotherapy (IPT) is a brief, attachment-focused psychotherapy that centers on resolving interpersonal problems and symptomatic recovery. It is an empirically supported treatment (EST) that follows a highly structured and time-limited approach and is intended to be completed within 12-16 weeks. IPT is based on the principle that relationships and life events impact mood and that the reverse is also true. Originally named «high contact» therapy, IPT was first developed in 1969 at Yale University as part of a study designed by G. Klerman, M. Weissman and colleagues to test the efficacy of an antidepressant with and without psychotherapy as maintenance treatment of depression. This approach focuses on the interaction between interpersonal dysfunction and psychological symptoms. IPT is founded on the idea that humans are social beings, thus client personal relationships lie at the center of presenting problems and psychological states. Although grounded in a medical model, which is used to conceptualize the client's presenting problem, the primary basis for this approach lies in an interpersonal modification of psychodynamic psychotherapy. Therapy is presentfocused, but aspects of attachment theory are used to analyze how past relationships affect current relationships. Therapists applying IPT take an active stance, continually and supportively guiding the sessions to maintain focus on one of four interpersonal problem areas: unresolved grief, role transitions, role disputes, or interpersonal deficits. Three principles guided this initial work: the use of a randomized controlled trial, using a broad range of standardized assessments, and recognition of the need to replicate study treatment findings before disseminating the treatment. The assessments included measures not only of symptoms but of social functioning and quality of life [6].

By exploring patterns and experiences in relationships and identifying and understanding problem areas, an individual can determine ways to resolve the difficulties causing them mental distress. The emphasis on building relationships and improving communication can help people 
understand how they are seen, how they impact on others, increase trust and self-confidence and create the basis for a more positive and balanced state of mental health. Treatment manuals have been translated into multiple languages (including Danish, French, German, Italian, Japanese, Portuguese and Spanish), and IPT is increasingly widely practiced in North and South America, Europe, Australia, New Zealand and elsewhere.

Integrative interpersonal model of personality psychopathology. Personality pathology indicates the overall level or severity of personality-related dysfunction, whereas personality disorders reflect symptom or trait constellations that vary across individuals with different disorders, independent of the severity of their overall personality pathology. Personality pathology explained most of the variance in functional outcomes, but the five personality disorder dimensions, which they labeled peculiarity, deliberateness, instability, withdrawal, and fearfulness, incremented this personality pathology for predicting several specific outcomes. L. S. Morey assessed personality pathology with items from questionnaires designed to assess global personality dysfunction. The contemporary interpersonal model presented here also explicitly distinguishes the definition of personality psychopathology from the description of individual differences in its expression. A. L. Pincus refers to this as the distinction between the genus-personality pathology and the speciespersonality disorder [3]. The interpersonal model of personality psychopathology combines the integrative developmental, motivational, and regulatory assumptions of interpersonal theory to define personality pathology with descriptive characteristics and dynamic processes systematized by the empirically derived IPC model, which is employed as a key conceptual map of interpersonal functioning to describe individual differences in personality disorder.

The purpose and objectives of research is a need to analyze the key aspects of integrative interpersonal theory of personality.

Main material and research results. The interpersonal circumplex is a comprehensive but parsimonious structural model for representing interpersonal dispositions. The circumplex is typically defined with reference to the orthogonal dimensions of agency (dominance, power, status) and communion (friendliness, warmth, love).

In terms popularized by D. Bakan (1966), two basic themes underlie social interactions: agency (getting ahead) and communion (getting along). When positioned as the axes of a two-dimensional space, agency and communion provide a powerful framework for representing individual differences in both normal and abnormal behavior (T. Leary, 1957).

Efforts to describe the structure of social behavior can be viewed in terms of two major categories: the multidimensional approaches which include as many dimensions as are needed to meet a given mathematical criterion, and the approaches which confine the number of dimensions to two or three so that a model can be constructed in real space. The multidimensional approach is exemplified by Cattell's 16 Personality Factor analysis of personality, and the real-space modeling approach is exemplified by Leary's (interpersonal circle). Leary's (1957) interpersonal circle itself was first described in a paper by M. Freedman, T. Leary, A. Ossorio, and was built on four nodal points: Dominate and submit were located opposite each other on the vertical axis, whereas love and hate were oppositional nodal points on the horizontal axis. Each category in the circle was defined in terms of these nodal points, so that, for example, boast was placed on the hate side of dominate, while teach appeared on the love side of dominate. J. L. Rinn ttempted to expand T. Leary's interpersonal circle so that it would apply to the intrapsychic domains of cognition and feeling as well as to social interaction. He suggested that models in these domains could be constructed such that specific cognitive attitudes and specific feelings would parallel specific interpersonal behaviors. For example, the behavior «affectionate» would be accompanied by the attitude «sociable» and the feeling «pleasant». Rinn's model does not comprehensively cover cognition and feeling, but the idea that cognition and feeling might have a structure which parallels interpersonal behaviors deserves further development [7]. 
Although most people say that they want to feel good, people want to feel good in different ways. Nowadays most interpersonal circumplex studies use either the Interpersonal Adjective ScalesRevised (IAS-R; 1995) or the Inventory of Interpersonal Problems-Circumplex (IIP-C; 1988). The IAS-R and IIP-C assess interpersonal traits and interpersonal problems, respectively [9].

Analyzing scientific sources, we can distinguish the components of integrative interpersonal theory of personality. Key concepts of interpersonal theory [3; 4; 11]: Copy process, Catalysts of internalization, Interpersonal motives, Regulatory Metagoals. Interpersonal Copy Processes. There are three developmental «copy processes» that describe the ways in which early interpersonal experiences are internalized as a function of achieving attachment, be it secure or insecure. Identification - treating others as one has been treated. To the extent that individuals strongly identify with early caretakers, there will be a tendency to act toward others in ways that copy how important others have acted toward the developing person. Recapitulation - maintaining a position complementary to an internalized other. This can be described as reacting «as if » the internalized other is still there. Introjection - treating the self as one has been treated. By treating the self in introjected ways, the internal interpersonal situation may promote security and esteem even while generating noncomplementary behavior in the proximal interpersonal situation.

Catalysts of internalization: developmental achievements and adult identity of traumatic learning. First, attachment, security, separation-individuation, positive affects, gender identity, resolution pf Oedipal dynamics, self-esteem, self-confirmation, mastery of unresolved conflicts - these themes and dynamics become the basis for the recurrent interpersonal situations that characterize a human life; Second, early loss of attachment figure, childhood illness or injury, physical abuse, sexual abuse, emotional abuse, parental neglect - interpersonal behaviors and patterns were associated with achievement or frustration of particular developmental milestones or were required to cope with stressors.

Identifying the developmental and traumatic catalysts for internalization and social learning of interpersonal themes and dynamics allows for greater understanding of current behavior.

Interpersonal motives: agentic (individuation, power, mastery, assertion, autonomy, status), communal (attachment, intimacy, belongingness, love), self-protective (regulatory strategies to cope with feeling of vulnerability arising from relational experience).

Beyond agentic and communal motives, contemporary interpersonal theory identifies a third class of interpersonal motives referred to as self-protective motives, which can be described as arising as a way of defending oneself from feelings of vulnerability that are related to relational schemas that often take the form of strategies people use to reassure themselves that they possess desired communal (e.g., likeable) and agentic (e. g., competent) self-qualities [8]. The former render the experience of most interpersonal situations functionally equivalent (and typically anxiety provoking and threatening to the self ), while the latter render the experience of interpersonal situations highly inconsistent and unpredictable (commonly oscillating between secure and threatening organizations of experience).

Regulatory metagoals: self-regulation (esteem, cohesion, control, focus, confidence); affect regulation (negativity affectivity, positive affectivity); field regulation (behavior/feeling of proximal others, affectivity internalized other).

The concept of regulation is ubiquitous in psychological theory, particularly in the domain of human development. Most theories of personality emphasize the importance of developing mechanisms for emotion regulation and self-regulation. Interpersonal theory is unique in its added emphasis on field regulation (i.e., the processes by which the behavior of self and other transactionally influence each other).

Interpersonal themes connote the interpersonal content of an individual's behavior. These themes can be mapped around the interpersonal circumplex. Interpersonal dynamics involve the nature of the core personality pathology processes as they unfold in interpersonal situations over time, including extremity, rigidity, and oscillation. 
Conclusions. It is concluded that interpersonal style in this study was conceptualized as traitlevel interpersonal behavior. Interpersonal theory asserts that, all forms of social behavior can in turn be viewed as combinations of the four poles. Notably, the present study did not include a clinical sample of individuals but thus, we see the contemporary interpersonal model as consistent with and more theoretically cohesive than the system to contextualize personality pathology within individual differences in personality

1. Alden, L. E., Wiggins, J. S., \& Pincus, A. L. (1990). Construction of circumplex scales for the Inventory of Interpersonal Problems. Journal of personality assessment, 55 (3-4), 521-536.

2. Gurtman, M. B. (2009). Exploring personality with the interpersonal circumplex. Social and personality psychology compass, 3 (4), 601-619.

3. Hopwood, C. J., Ansell, E. B., Pincus, A. L., Wright, A. G., Lukowitsky, M. R., \& Roche, M. J. (2011). The circumplex structure of interpersonal sensitivities. Journal of Personality, 79 (4), 707-740.

4. Horowitz, L. M., Rosenberg, S. E., Baer, B. A. (1988). Inventory of interpersonal problems: Psychometric properties and clinical applications. Journal of consulting and clinical psychology, 56 (6), 885-892.

5. Johnson, J., Weissman, M. M., \& Klerman, G. L. (1992). Service utilization and social morbidity associated with depressive symptoms in the community. Jama, 267(11), 1478-1483.

6. Kiesler, D. J. (1983). The 1982 interpersonal circle: A taxonomy for complementarity in human transactions. Psychological review, 90 (3), 185-214.

7. LaForge, R. (2004). The early development of the interpersonal system of personality (ISP). Multivariate Behavioral Research, 39 (2), 359-378.

8. Locke, K. D., \& Sadler, P. (2007). Self-efficacy, values, and complementarity in dyadic interactions: Integrating interpersonal and social-cognitive theory. Personality and Social Psychology Bulletin, 33 (1), 94-109.

9. Moskowitz, D. S. (1994). Cross-situational generality and the interpersonal circumplex. Journal of Personality and Social Psychology, 66 (5), 921-933.

10. Wiggins, J. S., Phillips, N., \& Trapnell, P. (1989). Circular reasoning about interpersonal behavior: Evidence concerning some untested assumptions underlying diagnostic classification. Journal of Personality and Social Psychology, 56 (2), 296-305.

11. Wright, A. G., Pincus, A. L., Conroy, D. E., \& Hilsenroth, M. J. (2009). Integrating methods to optimize circumplex description and comparison of groups. Journal of Personality Assessment, 91(4), 311-322. 


\section{Світлана Кузікова, Валерій Зливков, Світлана Лукомська СУЧАСНА ІНТЕГРАТИВНА ІНТЕРПЕРСОНАЛЬНА ТЕОРІЯ ОСОБИСТОСТІ: КЛЮЧОВІ АСПЕКТИ}

Стаття присвячена аналізу сучасної інтегративної міжособистісної теорії особистості, щзо базується на міжсособистісній теорії психіатрї, згідно з якою міжособистісна ситуаџія як одиниця аналізу дозволяє реалізувати міждисциплінарний підхід до діагностики, терапії та лікування патопсихологічних станів. При изьому наголошується, що утворений метаконструктами контекст комунікації по суті є моделлю міжособистісного комплексу, який дозволяє вивчати особистість комплексно, в контексті інтегративного підходу, базуючись не лище на принципах патологї, а й на принципах гуманізму. Окреслено основні поняття сучасної інтегративної міжособистісної теорії особистості: копінг-процеси, каталізатори інтерналізацї, міжособистісні мотиви, регуляторні метацілі. Проаналізовано численні дослідження (зокрема сучасні), щуо не лише розкривають основні поняття інтегративної міжособистісної теорії, а й демонструють можливості ї̈ використання у практичній психологї̈ та психотерапії. Встановлено, щьо застосування інтегративної міжособистісної теорії для вивчення ідеографічних (орієнтованих на людину) та номотетичних (орієнтованих на норми) сфер дозволяють розглядати особистість комплексно, у взаємозв'язку ї̈ різних властивостей. Сучасна міжособистісна традиція передбачає зумовленість соціального функціонування міжособистісним контекстом, тобто міжособистісний аспект у психології є номологічною мережею, яка забезпечує основу для інтегративного визначення особистості. 3 урахуванням надбань міжособистісної теорї та досвіду ї̈ використання у практичній психологї та психотерапії, констатується, щฺо ключові ї̈ аспекти можуть вважатися основними компонентами міждисциплінарної психологї̈ особистості.

Ключові слова: міжособистісний підхід, міжособистісний комплекс, особистість, самореалізація, комунікація. 